\title{
Development of a Cell-Based High-Throughput Assay to Screen for Inhibitors of Organic Anion Transporting Polypeptides 1B1 and 1B3
}

\author{
Chunshan Gui ${ }^{1}$, Amanda Obaidat ${ }^{1}$, Rathnam Chaguturu ${ }^{2,3}$ and Bruno Hagenbuch*,1,2 \\ ${ }^{I}$ Department of Pharmacology, Toxicology and Therapeutics, The University of Kansas Medical Center, Kansas City, \\ Kansas 66160, USA \\ ${ }^{2}$ The University of Kansas Cancer Center, Kansas City, Kansas 66160, USA \\ ${ }^{3}$ The High Throughput Screening Laboratory, The University of Kansas, Structural Biology Center, Lawrence, Kansas \\ 66045, USA
}

\begin{abstract}
The two organic anion transporting polypeptides (OATPs) 1B1 and 1B3 are expressed at the sinusoidal membrane of hepatocytes. They have a broad and overlapping substrate specificity and transport many endobiotics and drugs. Specific inhibitors are required to determine the contribution of each OATP to the hepatocellular uptake of common substrates. We have developed a cell-based high-throughput assay to screen chemical libraries in order to identify such inhibitors for OATP1B1 and OATP1B3. We have used OATP1B1- or OATP1B3-expressing Chinese Hamster Ovary cells on 96-well plates and determined uptake of fluorescein-methotrexate (FMTX). We validated the assay with known inhibitors and screened the well characterized Prestwick library of 1120 drugs. Along with several known OATP inhibitors including rifampicin, cyclosporine A and mifepristone we identified some new inhibitors. For inhibitors that seemed to be able to distinguish between OATP1B1- and OATP1B3-mediated FMTX uptake $\mathrm{IC}_{50}$ values were determined. Estropipate (estrone-3-sulfate stabilized with piperazine) was the most selective OATP1B1 inhibitor $\left(\mathrm{IC}_{50}=0.06 \mu \mathrm{M}\right.$ vs. $19.3 \mu \mathrm{M}$ for OATP1B3). Ursolic acid was the most selective OATP1B3 inhibitor $\left(\mathrm{IC}_{50}=2.3 \mu \mathrm{M}\right.$ vs. $12.5 \mu \mathrm{M}$ for OATP1B1). In conclusion, this cell-based assay should allow us to identify even more specific inhibitors by screening larger chemical libraries.
\end{abstract}

Keywords: OATP1B1, OATP1B3, fluorescein-methotrexate, cell based assay, high-throughput screening.

\section{INTRODUCTION}

Organic anion transporting polypeptides (humans: OATPs; rodents: Oatps) form a large gene superfamily of transport proteins expressed in multiple organs $[1,2]$. Many of their members are multispecific transporters that mediate the uptake of numerous endo- and xeno-biotics. Human OATP1B1 and OATP1B3 are expressed in the sinusoidal membrane of hepatocytes and are thought to be liver-specific under normal physiological conditions. They are responsible for the uptake of numerous drugs, including statins, endothelin receptor antagonists, anticancer drugs like methotrexate and paclitaxel, as well as the antibiotic rifampicin [1]. Besides specific substrates like prostaglandin $\mathrm{E}_{2}$ for OATP1B1 and CCK-8 for OATP1B3 [3, 4], OATP1B1 and OATP1B3 have a number of common drug substrates including bosentan [5], fluvastatin [6], methotrexate [7, 8], olmesartan [9], pitavastatin [10], rifampicin [11], rosuvastatin [12], and valsartan [13]. Given that both OATPs are expressed in human hepatocytes, it will be almost impossible without specific inhibitors to elucidate which of the two proteins is more important for the transport of a certain drug. Furthermore, these transporters can affect the bioavailability

*Address correspondence to this author at the Department of Pharmacology, Toxicology and Therapeutics, The University of Kansas Medical Center, 3901 Rainbow Blvd, Kansas City, KS 66160, USA; Tel: +1-913-588-0028; Fax:+1-913-588-7501; E-mail: bhagenbuch@kumc.edu of drugs. In 1996 we demonstrated that the peptide-based thrombin inhibitor CRC 220 is a substrate of rat Oatp1a1 [14]. This explained the very high hepatic first pass elimination of CRC 220 which was partially responsible for its low bioavailability. Specific OATP1B1 or OATP1B3 inhibitors could be co-applied with a drug which is efficiently cleared by the liver and this could increase its bioavailability.

In order to identify potentially specific inhibitors for OATP1B1 and OATP1B3, we decided to develop an assay for high-throughput screening. Fluorescent substrates are preferred for high-throughput screening because of the sensitivity and dynamic range that the fluorescence signal affords. So far only fluorescent bile acids [15] and Fluo-3, a fluorescent calcium indicator $[16,17]$ have been demonstrated to be substrates for OATP1B3 while fluorescein methotrexate (FMTX) has been reported as a substrate for OATP1B1 [18]. However, methotrexate has been shown to be a substrate for both OATP1B1 and OATP1B3 [8] and is commercially available as fluorescein methotrexate (FMTX) and Alexa Fluor ${ }^{\circledR} 488$ methotrexate (AMTX). Preliminary data from our laboratory also demonstrated that the anticancer drug paclitaxel is a substrate for both OATPs. A fluorescent version of paclitaxel is also available commercially as Oregon Green ${ }^{\circledR} 488$ Taxol (Flutax-2). Therefore, we compared these different fluorescent compounds along with fluorescein as substrates for OATP1B1 and OATP1B3. We further characterized FMTX transport by both OATPs and established an assay on 96-well plates for high-throughput screening. We 
used this assay to screen the Prestwick library for modulators (inhibitors or stimulators) and confirmed several hits by measuring $\mathrm{IC}_{50}$ or $\mathrm{EC}_{50}$ values for inhibition and stimulation of OATP1B1- and OATP1B3-mediated FMTX transport.

\section{MATERIALS AND METHODS}

\section{Materials}

Cell culture reagents, fluorescein-methotrexate (FMTX), Alexa Fluor ${ }^{\circledR} 488$ methotrexate (AMTX), and Oregon Green ${ }^{\circledR} 488$ Taxol (Flutax-2) were purchased from Invitrogen (Carlsbad, CA). Fetal bovine serum was from Hyclone (Logan, UT). The Prestwick library was obtained from the University of Kansas High Throughput Screening Laboratory. Individual chemicals for the confirmatory experiments were either from Prestwick Chemical or from Sigma and stock solutions were prepared in DMSO.

\section{Cell Culture and Transport Assay on 24-well Plates}

Chinese Hamster Ovary (CHO) cells stably expressing OATP1B1 and OATP1B3 were described previously [19] and were grown at $37{ }^{\circ} \mathrm{C}$ in a humidified $5 \% \mathrm{CO}_{2}$ atmosphere in Dulbecco's Modified Eagle Medium, containing 1 $\mathrm{g} / 1$ D-glucose, $2 \mathrm{mM}$ L-glutamine, $25 \mathrm{mM}$ Hepes buffer and $110 \mathrm{mg} / 1$ sodium pyruvate, supplemented with $10 \%$ FBS (Hyclone, Logan, UT), $50 \mu \mathrm{g} / \mathrm{ml}$ L-proline, $100 \mathrm{U} / \mathrm{ml}$ penicillin and $100 \mu \mathrm{g} / \mathrm{ml}$ streptomycin, and $500 \mu \mathrm{g} / \mathrm{ml} \mathrm{G}-418$. Cells were passaged twice a week and used up to passage 55 . Protein concentrations were very consistent, both on 24-well plates $(0.150 \pm 0.005 \mathrm{mg} / \mathrm{well})$ as well as on 96 -well plates $(0.045 \pm 0.002 \mathrm{mg} /$ well $)$. Transport assays on 24 -well plates were performed as described [19] with the following modifications: cells were washed three times with $1 \mathrm{ml}$ of prewarmed $\left(37^{\circ} \mathrm{C}\right)$ uptake buffer $(116.4 \mathrm{mM} \mathrm{NaCl}, 5.3 \mathrm{mM}$ $\mathrm{KCl}, 1 \mathrm{mM} \mathrm{NaH} \mathrm{PO}_{4}, 0.8 \mathrm{mM} \mathrm{MgSO} 4,5.5 \mathrm{mM}$ D-glucose and $20 \mathrm{mM}$ Hepes, $\mathrm{pH}$ adjusted to 7.4 with Trizma base) and uptake was started by adding $200 \mu \mathrm{l}$ of uptake buffer containing the indicated concentrations of fluorescent compound. After the indicated time period at $37^{\circ} \mathrm{C}$, uptake was stopped by removing the uptake solution and washing the cells four times with $1 \mathrm{ml}$ of ice-cold uptake buffer. The cell membranes were then disrupted with $300 \mu 1$ of $1 \%$ Triton X100 (dissolved in PBS) and fluorescence was measured in a Bio-Tek Synergy HT microplate reader (Winooski, VT) at an excitation wavelength of $485 \mathrm{~nm}$ and an emission wavelength of $528 \mathrm{~nm}$.

\section{High-Throughput Uptake Experiments in 96-well Plates}

For high-throughput uptake experiments, OATPexpressing CHO cells were plated at 12,000 cells per well on 96-well plates and 48 hours later medium was replaced with medium containing $5 \mathrm{mM}$ Na-butyrate to induce nonspecific gene expression. Previous experiments with OATP expressing $\mathrm{CHO}$ cells have demonstrated that after treatment of $\mathrm{CHO}$ cells with Na-butyrate transporter function was increased due to an increase in the maximal transport rate [20]. After another 24 hours in culture, the cells were used for uptake experiments. Cells were washed three times with 200 $\mu \mathrm{l}$ of room temperature uptake buffer $(116.4 \mathrm{mM} \mathrm{NaCl}, 5.3$ $\mathrm{mM} \mathrm{KCl}, 1 \mathrm{mM} \mathrm{NaH}{ }_{2} \mathrm{PO}_{4}, 0.8 \mathrm{mM} \mathrm{MgSO}_{4}, 5.5 \mathrm{mM}$ Dglucose and $20 \mathrm{mM}$ Hepes, $\mathrm{pH}$ adjusted to 7.4 with Trizma base) and uptake was started by adding $70 \mu$ l of uptake buffer containing $5 \mu \mathrm{M}$ substrate in the presence or absence of inhibitors. After 30 min culture at room temperature, uptake was stopped by removing the uptake solution and washing the cells four times with $200 \mu \mathrm{l}$ of room temperature uptake buffer. The cells were then solubilized with $100 \mu \mathrm{l}$ of $1 \%$ Triton X-100 (dissolved in PBS). Fluorescence was measured in a Bio-Tek Synergy HT microplate reader (Winooski, VT) at an excitation wavelength of $485 \mathrm{~nm}$ and an emission wavelength of $528 \mathrm{~nm}$.

\section{Data Analysis}

Z' factor calculation and assay validation were done according to NIH assay guidance manual [21]. The data were analyzed using Sigmaplot and Graphpad prism. Statistical significance was determined using the two-tailed unpaired Student's t test.

\section{RESULTS}

\section{Characterization of Fluorescent Substrate Transport by OATP1B1 and OATP1B3}

In the first set of experiments, we compared the uptake of four new fluorescent compounds, fluorescein-methotrexate (FMTX), Alexa Fluor ${ }^{\circledR} 488$ methotrexate (AMTX), Oregon Green ${ }^{\circledR} 488$ Taxol (Flutax-2) and fluorescein to the uptake of the known OATP substrate Fluo-3. As can be seen in Fig. (1), four of the five compounds namely Fluo-3, FMTX, Flutax-2 and fluorescein are substrates for OATP1B3, while AMTX was not transported. OATP1B1 on the other hand only transported FMTX and fluorescein. Given that radiolabeled methotrexate has previously been documented as a substrate for both OATP1B1 and OATP1B3 [8] and that the uptake signal for both OATP1B3 (about 4.5 fold) and OATP1B1 (about 3 fold) was highest for FMTX, we decided to further characterize it. As the results in Fig. (2) demonstrate, uptake of $10 \mu \mathrm{M}$ FMTX was linear over a 5 min period. Thus, we used the $2 \mathrm{~min}$ time point to determine the kinetic parameters of OATP-mediated FMTX transport. Fig. (3) shows one of three independent experiments and demon-

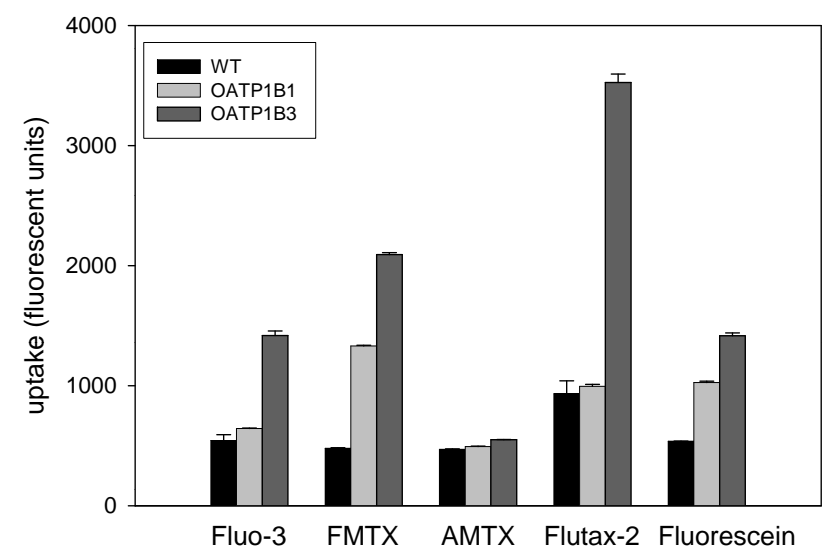

Fig. (1). Comparison of OATP1B1- and OATP1B3-mediated transport of fluorescent substrates. Uptake was measured with $1 \mu \mathrm{M}$ of the indicated fluorescent compounds on 24-well plates for $30 \mathrm{~min}$. Values are means \pm SE of two combined independent experiments each performed with triplicate determinations. FMTX: fluorescein methotrexate; AMTX: Alexa Fluor ${ }^{\circledR} 488$ methotrexate; Flutax-2: Oregon Green ${ }^{\circledR} 488$ Taxol; WT: wild-type CHO cells; OATP1B1: CHO cells expressing OATP1B1; OATP1B3: CHO cells expressing OATP1B3. 
strates that OATP1B3 (closed circles) has a much higher capacity than OATP1B1 (open circles) to transport FMTX. Based on all three experiments we calculated for OATP1B1 an apparent $\mathrm{K}_{\mathrm{m}}$ value of $3.8 \pm 0.7 \mu \mathrm{M}$ and a $\mathrm{V}_{\max }$ value of $961 \pm 198$ fluorescent units/mg protein $* \min$ and for OATP1B3 an apparent $\mathrm{K}_{\mathrm{m}}$ value of $7.9 \pm 2.0 \mu \mathrm{M}$ and a $\mathrm{V}_{\max }$ value of $4772 \pm 709$ fluorescent units/mg protein * min.

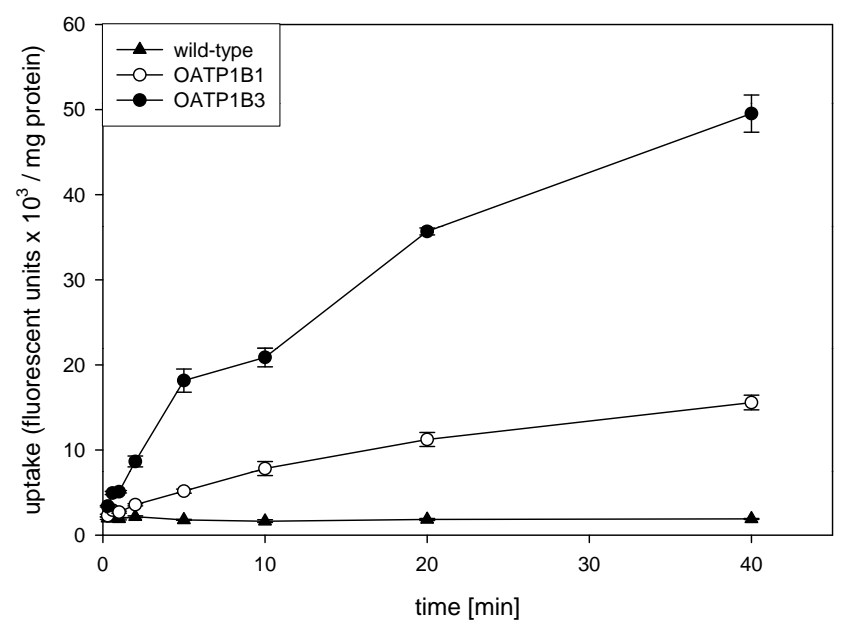

Fig. (2). Time dependent uptake of FMTX into CHO cells expressing OATP1B1 and OATP1B3. Uptake of $10 \mu \mathrm{M}$ FMTX was determined at $37{ }^{\circ} \mathrm{C}$ with wild-type (closed triangles), OATP1B1 (open circles) or OATP1B3 (closed circles) expressing CHO cells on 24-well plates. Values are means $\pm \mathrm{SE}$ of quadruplicate determinations in a single experiment.

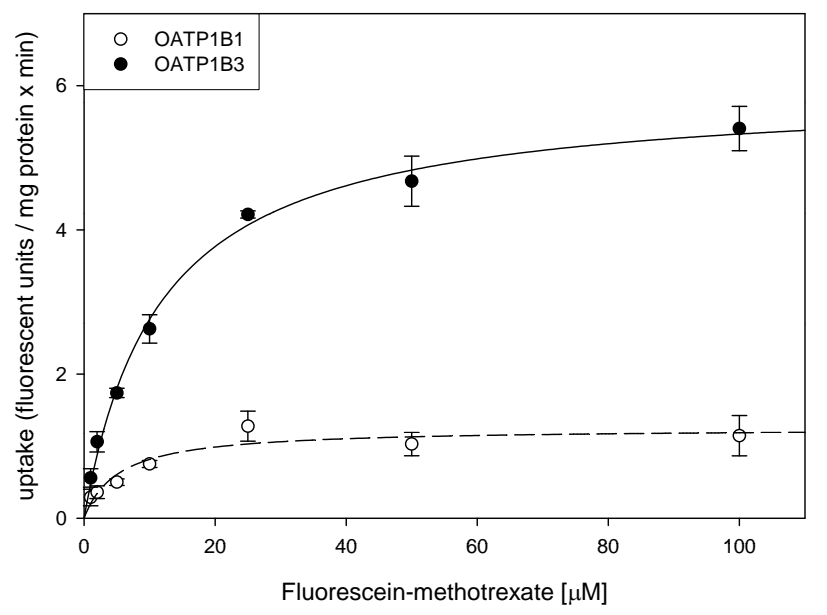

Fig. (3). Kinetics of OATP1B1- and OATP1B3-mediated FMTX uptake. Uptake of increasing concentrations of FMTX was measured at $37{ }^{\circ} \mathrm{C}$ for $2 \mathrm{~min}$ on 24-well plates with $\mathrm{CHO}$ wild-type and OATP1B1 or OATP1B3 expressing cells. Net OATP1B1 (open circles) or OATP1B3 (closed circles) uptake was calculated by subtracting uptake into wild-type cells from uptake into OATPexpressing cells. The values (means $\pm \mathrm{SE}$ ) were fitted to the Michaelis-Menten equation using non-linear regression analysis.

\section{Establishing a High-Throughput Assay on 96-well Plates}

In order to test whether this cell-based assay could be run on 96-well plates instead of on 24-well plates, we determined uptake of $5 \mu \mathrm{M}$ FMTX in the absence or presence of known OATP substrates or inhibitors for $30 \mathrm{~min}$ at room temperature on 96-well plates. We could detect FMTX uptake mediated by both OATPs. A typical uptake resulted in $4,400 \pm 80$ fluorescent units for wild-type CHO cells, 15,060 \pm 1,540 fluorescent units for OATP1B1-expressing cells and $33,880 \pm 3,645$ fluorescent units for OATP1B3-expressing cells. Thus, signal-to-basal ratios of 3.4 for OATP1B1 and of 7.7 for OATP1B3 were obtained. As can be seen from Fig. (4), uptake by OATP1B1 and OATP1B3 was inhibited by all tested compounds. In additional experiments (data not shown), we determined that uptake at room temperature was linear over at least $30 \mathrm{~min}$. Furthermore, we calculated the Z' factors for the assays $(0.26$ for OATP1B1 and 0.46 for OATP1B3) in the absence (negative control) and presence (positive control) of $10 \mu \mathrm{M}$ rifampicin with three independent 96-well plates. Validation was performed following the recommendations of the NIH assay guidance manual [21]. The coefficient of variance for all maximal signals, unnormalized middle signals and minimal signals was less than $20 \%$. Furthermore, all minimal signal standard deviations were smaller than both, the standard deviations of the middle and the maximal signals.
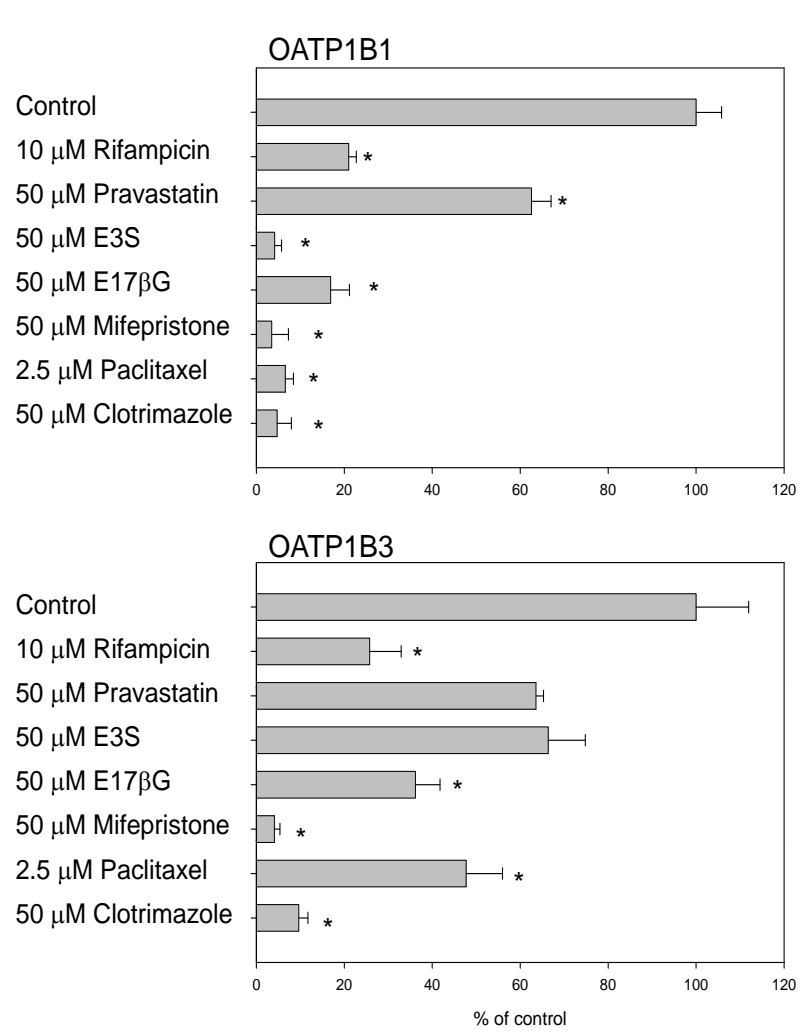

Fig. (4). Inhibition of OATP-mediated FMTX uptake by known inhibitors/substrates. Uptake of $5 \mu \mathrm{M}$ FMTX was measured for 30 min at room temperature on 96-well plates with OATP-expressing and wild-type $\mathrm{CHO}$ cells in the absence or presence of the indicated compounds. Values obtained with wild-type $\mathrm{CHO}$ cells were subtracted from values obtained with OATP-expressing cells and are given as percent of control. Means \pm SE of two combined independent experiments each performed with quadruplicate determinations are shown. $*$ p < 0.05; E3S: estrone-3-sulfate; E17 $\beta G$ : estradiol-17 $\beta$-glucuronide. 
Table 1. Statistics of Prestwick Library Screening

\begin{tabular}{|c|c|c|c|c|c|c|c|c|c|c|c|c|c|c|}
\hline OATP1B1 & & & & & & & & & & & & & & \\
\hline Plate number & 1 & 2 & 3 & 4 & 5 & 6 & 7 & 8 & 9 & 10 & 11 & 12 & 13 & 14 \\
\hline $\begin{array}{c}\text { Mean (neg } \\
\text { control) }\end{array}$ & 5,170 & 5,906 & 5,428 & 7,400 & 6,166 & 4,984 & 4,866 & 6,113 & 5,670 & 6,713 & 6,390 & 6,054 & 6,042 & 9,159 \\
\hline $\begin{array}{l}\text { STDEV (neg } \\
\text { control) }\end{array}$ & 390 & 1,107 & 807 & 924 & 579 & 645 & 451 & 721 & 634 & 1,150 & 425 & 605 & 444 & 921 \\
\hline $\begin{array}{c}\text { Mean (pos } \\
\text { control) }\end{array}$ & 9,411 & 10,044 & 9,499 & 14,100 & 10,904 & 9,080 & 8,950 & 11,267 & 10,641 & 11,879 & 12,990 & 12,183 & 14,967 & 16,572 \\
\hline $\begin{array}{l}\text { STDEV (pos } \\
\text { control) }\end{array}$ & 871 & 715 & 753 & 1,520 & 1,267 & 803 & 537 & 1,042 & 935 & 1,663 & 954 & 1,226 & 1,249 & 1,760 \\
\hline Sample mean & 9,654 & 10,381 & 9,101 & 13,350 & 9,857 & 8,448 & 8,967 & 11,136 & 10,397 & 11,423 & 12,343 & 11,735 & 12,785 & 16,997 \\
\hline$Z^{\prime}$ factor & 0.11 & -0.32 & -0.15 & -0.09 & -0.17 & -0.06 & 0.27 & -0.03 & 0.05 & -0.63 & 0.37 & 0.10 & 0.43 & -0.08 \\
\hline \multicolumn{15}{|l|}{ OATP1B3 } \\
\hline Plate number & 1 & 2 & 3 & 4 & 5 & 6 & 7 & 8 & 9 & 10 & 11 & 12 & 13 & 14 \\
\hline $\begin{array}{c}\text { Mean (neg } \\
\text { control) }\end{array}$ & 7,161 & 8,034 & 7,766 & 10,591 & 7,901 & 7,506 & 7,734 & 9,639 & 8,273 & 8,231 & 8,418 & 9,093 & 9,047 & 9,856 \\
\hline $\begin{array}{l}\text { STDEV (neg } \\
\text { control) }\end{array}$ & 760 & 1,315 & 1,037 & 1,814 & 523 & 834 & 1,194 & 1,495 & 761 & 332 & 370 & 472 & 570 & 1,026 \\
\hline $\begin{array}{c}\text { Mean (pos } \\
\text { control) }\end{array}$ & 26,768 & 31,694 & 27,097 & 31,987 & 28,351 & 25,272 & 30,369 & 26,319 & 26,882 & 30,781 & 31,653 & 34,132 & 34,603 & 32,986 \\
\hline $\begin{array}{l}\text { STDEV (pos } \\
\text { control) }\end{array}$ & 1,704 & 2,889 & 1,778 & 1,212 & 1,789 & 2,271 & 2,257 & 1,792 & 1,171 & 4,063 & 1,281 & 3,003 & 3,917 & 3,014 \\
\hline Sample mean & 26,308 & 26,850 & 23,819 & 33,715 & 26,838 & 25,368 & 25,738 & 29,565 & 26,661 & 29,799 & 29,365 & 33,188 & 31,714 & 36,503 \\
\hline$Z^{\prime}$ factor & 0.62 & 0.47 & 0.56 & 0.58 & 0.66 & 0.48 & 0.54 & 0.41 & 0.69 & 0.42 & 0.79 & 0.58 & 0.47 & 0.48 \\
\hline
\end{tabular}

\section{Screening of Prestwick Library}

To screen the 1120 compounds in the Prestwick library, we included 8 wells of negative (DMSO controls) and 8 wells of positive $(10 \mu \mathrm{M}$ rifampicin in DMSO) controls in each plate. As can be seen from the screening statistics shown in Table 1, we have developed a useful assay to screen for OATP1B3 inhibitors but the assay needs to be improved to be used with OATP1B1. Z' values for the OATP1B1 part were close to zero or even negative, while the values for the OATP1B3 part were between 0.41 and 0.79. Nevertheless, we identify inhibitors for both OATP1B1 and OATP1B3 mediated uptake and a stimulator for OATP1B3. Among the strongest inhibitors found were known OATP substrates and/or inhibitors like cyclosporine A, rifampicin, saquinavir and several statins. In addition to these compounds, several new substances were found to inhibit FMTX transport mediated by either OATP1B1 or OATP1B3 or by both.

To confirm these hits of the screening results, we determined $\mathrm{IC}_{50}$ values for several compounds that preferentially inhibited either OATP1B1 or OATP1B3 or seemed to stimulate one or the other OATP. Among the tested compounds we identified five compounds that inhibited OATP1B1 more potently than OATP1B3 and three that preferentially inhibited OATP1B3 mediated FMTX transport (Table 2, Fig. 5).
Estropipate, which is estrone-sulfate stabilized with piperazine, was the strongest OATP1B1 inhibitor with an $\mathrm{IC}_{50}$ of $0.06 \pm 0.01 \mu \mathrm{M}$, while it hardly inhibited OATP1B3 at concentrations up to $1 \mu \mathrm{M}\left(\mathrm{IC}_{50}\right.$ of $\left.19.3 \pm 6.3 \mu \mathrm{M}\right)$ (Table 2). In addition to estropipate, we found that bromocryptine, ergocryptine, fipexide, niflumic acid and repaglinide preferentially inhibited OATP1B1 (Table 2, Fig. 5), while beclamethasone, moricizine and ursolic acid preferentially inhibited OATP1B3 (Table 2, Fig. 5). Among the potential stimulators we could confirm that progesterone stimulated OATP1B3-mediated FMTX uptake with an $\mathrm{EC}_{50}$ of $0.2 \mu \mathrm{M}$, while it inhibited OATP1B1-mediated FMTX uptake with an $\mathrm{IC}_{50}$ of $5.4 \pm 1.9 \mu \mathrm{M}$ (Fig. 6).

\section{DISCUSSION}

In this study, we established a good high-throughput assay for OATP1B3 ( $Z$ ' factor > 0.4) that allows screening for inhibitors and stimulators of OATP1B3. The assay established for OATP1B1 needs more optimization perhaps using a different substrate to be as valuable as the one for OATP1B3. Initially we tested several fluorescent compounds as potential substrates for OATP1B1 and OATP1B3 and compared them to the known OATP1B1 and OATP1B3 substrate Fluo-3 [16, 17, 19]. Because fluoresceinmethotrexate (FMTX) resulted in the highest signal for both OATP1B1 and OATP1B3 and because radiolabeled 
Table 2. Inhibition of OATP1B1- and OATP1B3-Mediated Fluorescein-Methotrexate (FMTX) Uptake by Prestwick Library Compounds

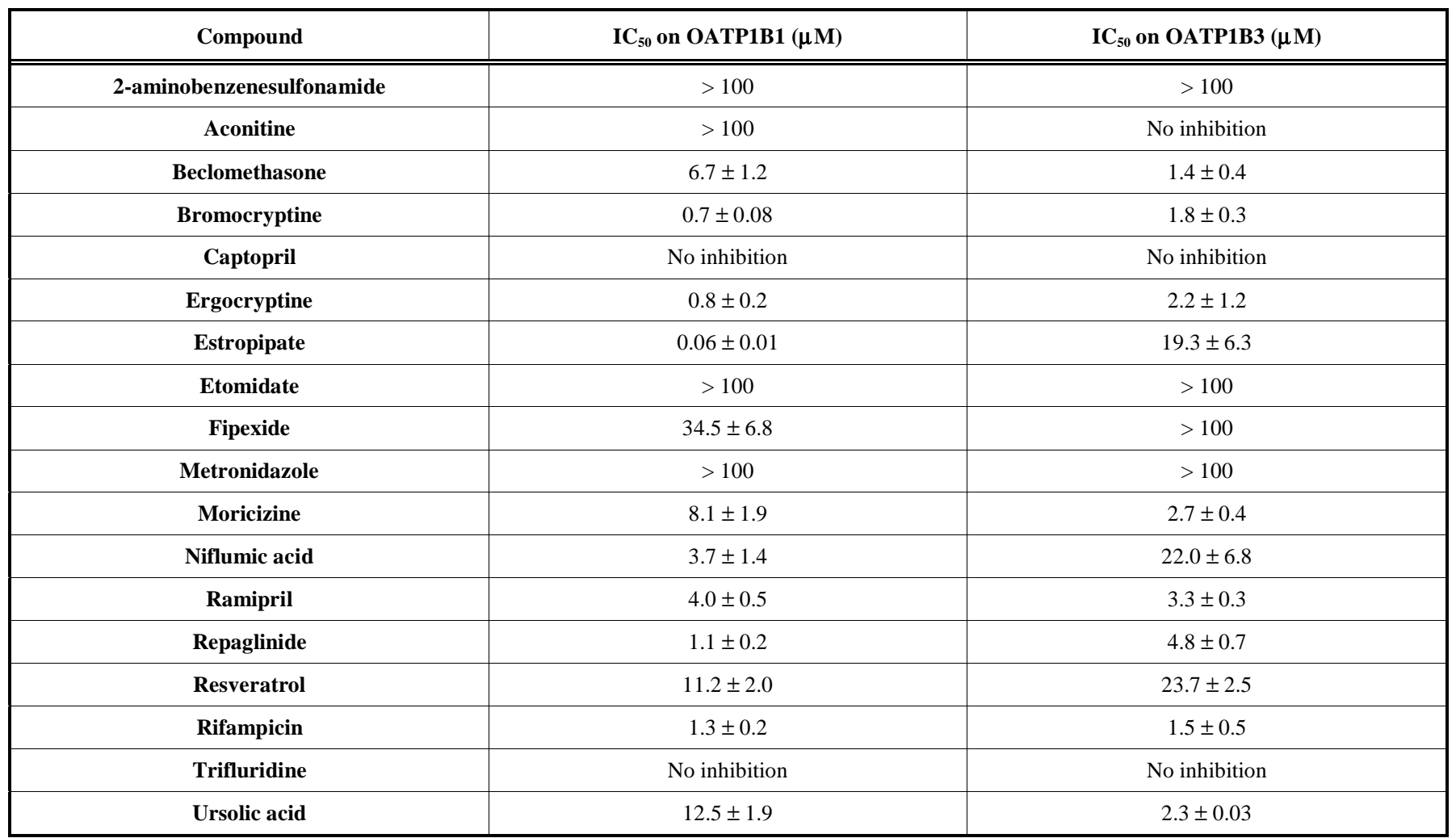

Results are means \pm SE of at least three independent experiments.
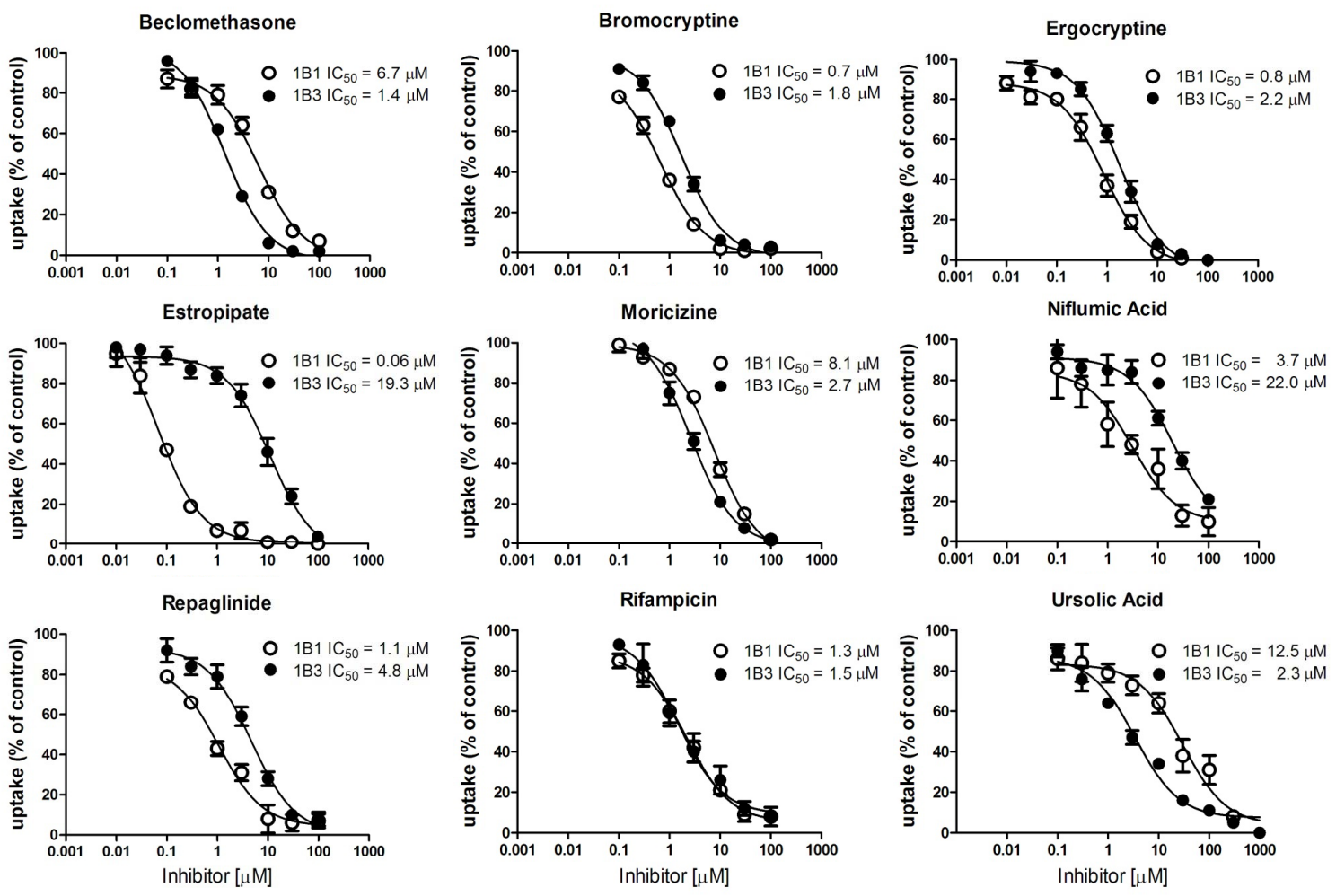

Fig. (5). Inhibition of OATP-mediated FMTX uptake by selected Prestwick compounds. Concentration dependent inhibition of $5 \mu$ M FMTX by indicated compounds was measured for $30 \mathrm{~min}$ at room temperature on 96-well plates with wild-type and OATP-expressing CHO cells. Values obtained with wild-type $\mathrm{CHO}$ cells were subtracted from values obtained with OATP-expressing cells and are given as percent of control. Means $\pm \mathrm{SE}$ of the means of three independent experiments are shown and were used to calculate $\mathrm{IC}_{50}$ values. 
OATP1B1

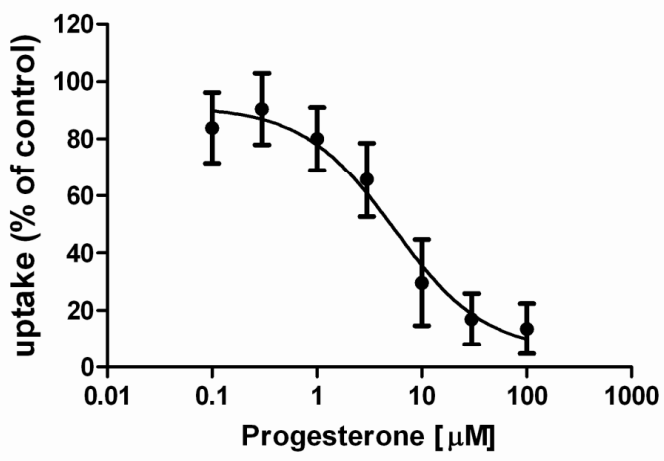

OATP1B3

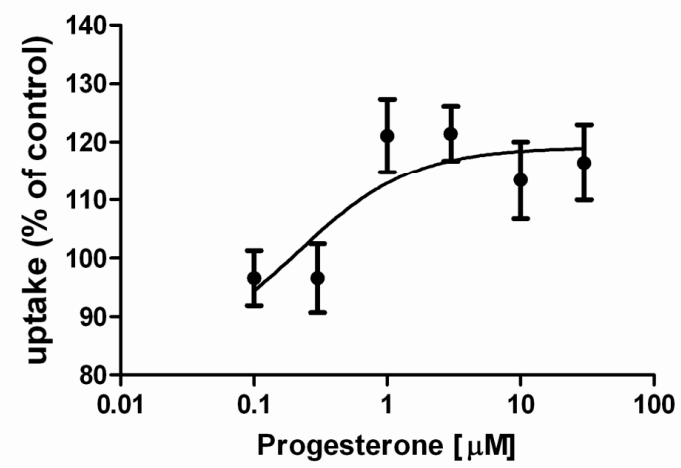

Fig. (6). Effect of progesterone on OATP1B1- and OATP1B3-mediated FMTX uptake. Concentration dependent inhibition of OATP1B1mediated and stimulation of OATP1B3-mediated $5 \mu \mathrm{M}$ FMTX uptake was measured for 30 min at room temperature on 96-well plates with wild-type and OATP-expressing CHO cells. Values obtained with wild-type CHO cells were subtracted from values obtained with OATPexpressing cells and are given as percent of control. Means \pm SE of two combined independent experiments each performed in quadruplicates are shown and were used to calculate $\mathrm{IC}_{50}$ and $\mathrm{EC}_{50}$ values, respectively.

methotrexate has previously been identified as a substrate for both OATP1B1 and OATP1B3 [8], we decided to continue with this substrate and further characterize its transport. Our results show that FMTX is transported by both OATPs (Figs. $\mathbf{1}, \mathbf{2}$ and $\mathbf{3}$ ) and the kinetic parameters suggest that OATP1B3 has a 2-3 fold higher efficiency $\left(\mathrm{V}_{\max } / \mathrm{K}_{\mathrm{m}}=604\right)$ than OATP1B1 $\left(\mathrm{V}_{\max } / \mathrm{K}_{\mathrm{m}}=252\right)$ to transport FMTX. This is similar to the transport of Fluo-3 which is also transported much better by OATP1B3 than by OATP1B1 [19], suggesting that the fluorescent moiety might be more important for recognition of FMTX by these two OATPs than the methotrexate moiety. This hypothesis is further supported by the finding that inhibition of OATP1B1-mediated pitavastatin uptake by methotrexate was very weak $\left(\mathrm{K}_{\mathrm{i}}>300 \mu \mathrm{M}\right)$ [22] and by our own observations that methotrexate at 100 $\mu \mathrm{M}$ only inhibited OATP-mediated FMTX uptake by $30 \%$ (data not shown). Therefore, it is likely that additional fluorescein-conjugates are transported by OATP1B1 and OATP1B3. Along the same lines, we also tested fluorescein itself and found that it is indeed a substrate for both transporters. However, the apparent affinity constants were about 10 fold higher for fluorescein $\left(\mathrm{K}_{\mathrm{m}}\right.$ OATP1B1 $38 \pm 5 \mu \mathrm{M} ; \mathrm{K}_{\mathrm{m}}$ OATP1B3 $82 \pm 10 \mu \mathrm{M})$ than for FMTX $\left(\mathrm{K}_{\mathrm{m}}\right.$ OATP1B1 3.8 $\pm 0.7 \mu \mathrm{M} ; \mathrm{K}_{\mathrm{m}}$ OATP1B3 $7.9 \pm 2.0 \mu \mathrm{M}$ ), suggesting that FMTX is the better substrate and that more than just the fluorescein moiety of the FMTX molecule is recognized by the transporters.

After having established that FMTX is a substrate for both OATP1B1 and OATP1B3, we tested the transport assay on 96-well plates at room temperature which would allow us to perform high-throughput screening. There was clear uptake signal for OATP1B1 and OATP1B3 (3.5 fold for OATP1B1 and 7.7 fold for OATP1B3) which could be inhibited by several common OATP substrates (Fig. 4).

Although the $Z$ ' factors were not very high ( 0.26 for OATP1B1 and 0.46 for OATP1B3), we screened the Prestwick library and observed several hits for both OATPs. The screening statistics (Table 1) confirmed that the assay is very useful with respect to OATP1B3 but needs improvement for OATP1B1. We are currently testing additional fluorescent compounds as substrates, in particular for OATP1B1, in or- der to increase the signal and establish a reliable assay also for OATP1B1. In the follow-up experiments, we determined $\mathrm{IC}_{50}$ values for several inhibitors identified by the primary screening for the inhibition of $5 \mu \mathrm{M}$ FMTX transported by either OATP. Some of the compounds that seemed to be stimulators during the primary screening could not be confirmed as stimulators, but inhibited slightly at higher concentrations and are listed with $\mathrm{IC}_{50}$ values larger than $100 \mu \mathrm{M}$ (2-aminobenxenesulfonamide, aconitine, etomidate, metronidazole and trifluridine). The only stimulator that could be confirmed was progesterone which stimulated OATP1B3mediated transport but inhibited OATP1B1-mediated transport. Progesterone has previously been shown to also stimulate OATP2B1- mediated estrone-3-sulfate uptake [23].

Rifampicin which inhibited FMTX uptake of both OATPs with an $\mathrm{IC}_{50}$ of 1.3 to $1.5 \mu \mathrm{M}$ (Table 2) has previously been shown to be an inhibitor and substrate for both OATPs [11] and has since been used to characterize OATP mediated transport by many groups. However, inhibition by rifampicin is dependent on the transported substrate. Fexofenadine has been inhibited by rifampicin with $K_{i}$ values of $0.5 \mu \mathrm{M}$ for OATP1B1 and of $1.5 \mu \mathrm{M}$ for OATP1B3 [24] while BSP was inhibited with $\mathrm{K}_{\mathrm{i}}$ values of $17 \mu \mathrm{M}$ for OATP1B1 and $5 \mu \mathrm{M}$ for OATP1B3 [11]. Treiber et al. [5] reported inhibition of bosentan transport with $\mathrm{IC}_{50}$ values of $3.2 \mu \mathrm{M}$ for OATP1B1 and 1.6 $\mu \mathrm{M}$ for OATP1B3 while uptake of the bosentan metabolite Ro 48-5033 was inhibited with $\mathrm{IC}_{50}$ values of about $50 \mu \mathrm{M}$ for OATP1B1 and $0.8 \mu \mathrm{M}$ for OATP1B3. These data clearly demonstrate substrate dependent inhibition patterns for OATP1B1 and OATP1B3mediated transport. Previously, $\mathrm{IC}_{50}$ values between 0.9 and $1.5 \mu \mathrm{M}$ for inhibition of OATP1B1 and $2.6 \mu \mathrm{M}$ for OATP1B3 mediated estradiol-17 $\beta$-glucuronide have been reported $[19,25]$. These values are in good agreement with the values obtained in this study with FMTX and could indicate that estradiol-17 $\beta$-glucuronide and FMTX are handled by the transporters in a very similar way while bosentan and its metabolite are probably transported via a different substrate binding site or translocation pathway given that the inhibition affinities are reversed. Based on the same assumptions it can be concluded that BSP and FMTX are probably 
handled in a very similar way given that $\mathrm{IC}_{50}$ values of repaglinide inhibition for OATP1B1 and OATP1B3 obtained in this study are very similar to the ones obtained with BSP as a substrate [26]. Thus, the results of this study confirm that it is important to keep in mind that multispecific transporters like OATP1B1 and OATP1B3 seem to have multiple overlapping substrate binding/transport sites that are also affected by inhibitors in a substrate dependent way.

Estropipate (estrone-sulfate stabilized with piperazine) was the only compound among the real inhibitors that can be considered selective for OATP1B1-mediated FMTX transport. It inhibited OATP1B1 with an $\mathrm{IC}_{50}$ value of $0.06 \mu \mathrm{M}$, while the $\mathrm{IC}_{50}$ value for OATP1B3-mediated FMTX transport was approximately 320-fold higher (Table 2). Besides indocyanine green which has been shown to be a specific inhibitor for OATP1B1-mediated estradiol-17 $\beta$-glucuronide transport while not affecting OATP1B3-mediated estradiol$17 \beta$-glucuronide transport at concentrations up to $10 \mu \mathrm{M}$ [27], estropipate is as far as we know the only other selective inhibitor that inhibits OATP1B1 with hardly any effect on OATP1B3 at concentrations up to $1 \mu \mathrm{M}$ at which concentration it completely inhibits OATP1B1 (Fig. 5). The most selective OATP1B3 inhibitors we identified were ursolic acid and beclomethasone that were about 5-fold more selective for OATP1B3 than for OATP1B1, but they were not as selective as the two OATP1B3 selective inhibitors T-3095 and T-3157 [28].

In conclusion, we have established that FMTX is a substrate for OATP1B1 and OATP1B3 and that it can be used for high-throughput screening with OATP1B3. Using this assay we have identified estropipate as a selective inhibitor for OATP1B1-mediated FMTX transport, and ursolic acid and beclomethasone as preferential inhibitors for OATP1B3mediated FMTX transport. To identify additional more specific OATP1B1 and OATP1B3 inhibitors, we are currently improving the assay especially for OATP1B1 and then plan to extend the screening to larger libraries that are available at the High Throughput Laboratory of the University of Kansas.

\section{ACKNOWLEDGEMENTS}

This work was supported by National Institute of Health grants RR021940, GM077336 and T32-ES07079. The University of Kansas high throughput screening laboratory is a KU Cancer Center Shared Resource, and is funded in part by NIH/NCRR COBRE grant P20 RR015563.

\section{REFERENCES}

[1] Hagenbuch B, Gui C. Xenobiotic transporters of the human organic anion transporting polypeptides (OATP) family. Xenobiotica 2008; 38: 778-801.

[2] Hagenbuch B, Meier PJ. Organic anion transporting polypeptides of the OATP/ SLC21 family: phylogenetic classification as OATP/ SLCO superfamily, new nomenclature and molecular/functional properties. Pflugers Arch 2004; 447: 653-65.

[3] Kullak-Ublick GA, Ismair MG, Stieger B, Landmann L, Huber R, Pizzagalli F, Fattinger K, Meier PJ, Hagenbuch B. Organic aniontransporting polypeptide B (OATP-B) and its functional comparison with three other OATPs of human liver. Gastroenterology 2001; 120: 525-33.

[4] Ismair MG, Stieger B, Cattori V, Hagenbuch B, Fried M, Meier PJ, Kullak-Ublick GA. Hepatic uptake of cholecystikinin octapeptide by organic anion-transporting polypeptides OATP4 and OATP8 of rat and human liver. Gastroenterology 2001; 121: 1185-90.
[5] Treiber A, Schneiter R, Hausler S, Stieger B. Bosentan is a substrate of human OATP1B1 and OATP1B3: inhibition of hepatic uptake as the common mechanism of its interactions with cyclosporin A, rifampicin, and sildenafil. Drug Metab Dispos 2007; 35: 1400-7.

[6] Kopplow K, Letschert K, Konig J, Walter B, Keppler D. Human hepatobiliary transport of organic anions analyzed by quadrupletransfected cells. Mol Pharmacol 2005; 68: 1031-8.

[7] Abe T, Kakyo M, Tokui T, Nakagomi R, Nishio T, Nakai D, Nomura H, Unno M, Suzuki M, Naitoh T, Matsuno S, Yawo H. Identification of a novel gene family encoding human liver-specific organic anion transporter LST-1. J Biol Chem 1999; 274: 1715963.

[8] Abe T, Unno M, Onogawa T, Tokui T, Kondo TN, Nakagomi R, Adachi H, Fujiwara K, Okabe M, Suzuki T, Nunoki K, Sato E, Kakyo M, Nishio T, Sugita J, Asano N, Tanemoto M, Seki M, Date F, Ono K, Kondo Y, Shiiba K, Suzuki M, Ohtani H, Shimosegawa T, Iinuma, Nagura H, Ito S, Matsuno S. LST-2, a human liverspecific organic anion transporter, determines methotrexate sensitivity in gastrointestinal cancers. Gastroenterology 2001; 120: 1689-99.

[9] Nakagomi-Hagihara R, Nakai D, Kawai K, Yoshigae Y, Tokui T, Abe T, Ikeda T. OATP1B1, OATP1B3, and mrp2 are involved in hepatobiliary transport of olmesartan, a novel angiotensin II blocker. Drug Metab Dispos 2006; 34: 862-9.

[10] Hirano M, Maeda K, Shitara Y, Sugiyama Y. Contribution of OATP2 (OATP1B1) and OATP8 (OATP1B3) to the hepatic uptake of pitavastatin in humans. J Pharmacol Exp Ther 2004; 311: 13946.

[11] Vavricka SR, van Montfoort J, Ha HR, Meier PJ, Fattinger K. Interactions of rifamycin SV and rifampicin with organic anion uptake systems of human liver. Hepatology 2002; 36: 164-72.

[12] Ho RH, Tirona RG, Leake BF, Glaeser H, Lee W, Lemke CJ, Wang Y, Kim RB. Drug and bile acid transporters in rosuvastatin hepatic uptake: function, expression, and pharmacogenetics. Gastroenterology 2006; 130: 1793-806.

[13] Yamashiro W, Maeda K, Hirouchi M, Adachi Y, Hu Z, Sugiyama Y. Involvement of transporters in the hepatic uptake and biliary excretion of valsartan, a selective antagonist of the angiotensin II AT1-receptor, in humans. Drug Metab Dispos 2006; 34: 1247-54.

[14] Eckhardt U, Horz JA, Petzinger E, Stuber W, Reers M, Dickneite G, Daniel H, Wagener M, Hagenbuch B, Stieger B, Meier PJ. The peptide-based thrombin inhibitor CRC 220 is a new substrate of the basolateral rat-liver organic anion-transporting polypeptide. Hepatology 1996; 24: 380-4.

[15] Yamaguchi H, Okada M, Akitaya S, Ohara H, Mikkaichi T, Ishikawa H, Sato M, Matsuura M, Saga T, Unno M, Abe T, Mano N, Hishinuma T, Goto J. Transport of fluorescent chenodeoxycholic acid via the human organic anion transporters OATP1B1 and OATP1B3. J Lipid Res 2006; 47: 1196-202.

[16] Cui Y, Konig J, Keppler D. Vectorial transport by doubletransfected cells expressing the human uptake transporter SLC21A8 and the apical export pump ABCC2. Mol Pharmacol 2001; 60: 934-43.

[17] Baldes C, Koenig P, Neumann D, Lenhof HP, Kohlbacher O, Lehr CM. Development of a fluorescence-based assay for screening of modulators of human Organic Anion Transporter 1B3 (OATP1B3). Eur J Pharm Biopharm 2006; 62: 39-43.

[18] Hassan NJ, Pountney DJ, Ellis C, Mossakowska DE. BacMam recombinant baculovirus in transporter expression: a study of BCRP and OATP1B1. Protein Expr Purif 2006; 47: 591-8.

[19] Gui C, Miao Y, Thompson L, Wahlgren B, Mock M, Stieger B, Hagenbuch B. Effect of pregnane $\mathrm{X}$ receptor ligands on transport mediated by human OATP1B1 and OATP1B3. Eur J Pharmacol 2008; 584: 57-65.

[20] Eckhardt U, Schroeder A, Stieger B, Höchli M, Landmann L, Tynes R, Meier PJ, Hagenbuch B. Polyspecific substrate uptake by the hepatic organic anion transporter oatp1 in stably transfected CHO cells. Am J Physiol 1999; 276: G1037-G42.

[21] Company ELa, Center NCG. Assay Guidance Manual Version 5.0. 2008; http://www.ncgc.nih.gov/guidance/manual_toc.html (last accessed [11/18/2009]).

[22] Hirano M, Maeda K, Shitara Y, Sugiyama Y. Drug-drug interaction between pitavastatin and various drugs via OATP1B1. Drug Metab Dispos 2006; 34: 1229-36. 
[23] Grube M, Kock K, Karner S, Reuther S, Ritter CA, Jedlitschky G, Kroemer HK. Modification of OATP2B1-mediated transport by steroid hormones. Mol Pharmacol 2006; 70: 1735-41.

[24] Matsushima S, Maeda K, Ishiguro N, Igarashi T, Sugiyama Y. Investigation of the inhibitory effects of various drugs on the hepatic uptake of fexofenadine in humans. Drug Metab Dispos 2008; 36: 663-9.

[25] Tirona RG, Leake BF, Wolkoff AW, Kim RB. Human organic anion transporting polypeptide-C (SLC21A6) is a major determinant of rifampin-mediated pregnane $\mathrm{X}$ receptor activation. $\mathrm{J}$ Pharmacol Exp Ther 2003; 304: 223-8.
[26]

Bachmakov I, Glaeser H, Fromm MF, Konig J. Interaction of oral antidiabetic drugs with hepatic uptake transporters: focus on organic anion transporting polypeptides and organic cation transporter 1. Diabetes 2008; 57: 1463-9.

[27] Cui Y, König J, Leier I, Buchholz U, Keppler D. Hepatic uptake of bilirubin and its conjugates by the human organic anion transporter SLC21A6. J Biol Chem 2001; 276: 9626-30.

[28] Nakakariya M, Shimada T, Irokawa M, Maeda T, Tamai I. Identification and species similarity of OATP transporters responsible for hepatic uptake of beta-lactam antibiotics. Drug Metab Pharmacokinet 2008; 23: 347-55.

Received: September 24, 2009

(c) Gui et al.; Licensee Bentham Open.

This is an open access article licensed under the terms of the Creative Commons Attribution Non-Commercial License (http://creativecommons.org/licenses/by-nc/3.0/) which permits unrestricted, non-commercial use, distribution and reproduction in any medium, provided the work is properly cited. 